\title{
Biologic Role of Fetal Lung Fibroblast Triglycerides as Antioxidants
}

\author{
J. S. TORDAY, D. P. TORDAY, J. GUTNICK, J. QIN, AND V. REHAN \\ Division of Neonatology, Department of Pediatrics, Harbor-UCLA Medical Center, Research and \\ Education Institute, RB-1, Torrance, California, U.S.A.
} \begin{abstract}
ABSTR
The pulmonary response to hyperoxia is highly variable,
depending on such seemingly disparate biologic factors as ges-
tational age, sex, hormonal milieu, and nutritional status. De-
scriptively, the magnitude and direction of these biologic differ-
ences in response to hyperoxia correlate with the triglyceride
content of developing fetal rat lung fibroblasts (FRLFs). Mech-
anistically, these same factors affect the triglyceride content of
FRLFs, e.g. d 21 FRLFs contain more triglyceride than d 18
FRLFs; female FRLFs contain more triglyceride than male
FRLFs (d 20); dexamethasone increases FRLF triglyceride con-
tent, dihydrotestosterone decreases it; nutritionally, exposure of
FRLFs to graded amounts of serum triglyceride (0\%, $2 \%$, $10 \%$,
20\%) results in increased intracellular FRLF triglyceride content.
To test the hypothesis that these biologic differences in intracel-
lular triglyceride content may account for differences in the
cytoprotection of lung fibroblasts against oxidant injury, fibro-
blast cultures representing each of these biologic groups were
challenged with graded doses of the reactive oxygen species
hydrogen peroxide ( $0.1-1.0$ mM for 5 min). The number of
surviving cells and their antioxidant status, as measured by lipid
peroxidation and glutathione content of the surviving cells, were
determined. We found that in response to hydrogen peroxide 1 )
\end{abstract}
ABSTRACT

d 21 FRLFs were more resistant than d 18 FRLFs; 2) female FRLFs were more resistant than male FRLFs; 3) dexamethasonetreated FRLFs were more resistant than dihydrotestosteronetreated fibroblasts; 4) fibroblasts fed increasing amounts of serum triglycerides were increasingly resistant to hydrogen peroxide; 5) cell survival in different serum triglyceride- and hormone-treated groups was not related to the antioxidant status as measured by glutathione content. These data are consistent with the hypothesized role of FRLF triglycerides as antioxidants. (Pediatr Res 49: 843-849, 2001)

\section{Abbreviations:}

FRLF, fetal rat lung fibroblast

$\mathbf{H}_{2} \mathbf{O}_{2}$, hydrogen peroxide

MDA, malondialdehyde

4HNE, 4-hydroxy-2-(E)-nonenal

GSH, glutathione

DHT, dihydrotestosterone

DEX, dexamethasone

AOE, antioxidant enzyme

DMEM, Dulbecco's minimal essential medium
The pulmonary response to hyperoxia is highly varied, depending on such seemingly disparate biologic factors as gestational age (1), sex (2), hormonal milieu (3), and nutritional status (4). Previous studies of the possible relationship between these biologic variables and classic AOE mechanisms have failed to support a causal relationship (5-7), leaving the biologic nature of the antioxidant protective mechanism unexplained. As an alternative hypothesis, cellular triglycerides have been found to act as antioxidants in a number of cell types, including endothelium (8), epithelium (9), and fibroblasts (10), both in vivo (11) and in vitro (12).

Several lines of evidence suggest that lipids are cytoprotective against oxygen free radical injury in vitro and in vivo.

Received July 21, 2000; accepted December 21, 2000.

Correspondence and reprint requests: John S. Torday, Ph.D., Harbor-UCLA Medical Center, Research and Education Institute, RB-1, 1124 West Carson Street, Torrance, CA 90502, U.S.A.; e-mail: jtorday@prl.humc.edu

Supported by NIH grant HL-55268.
Investigators have suggested that the greater oxygen tolerance of newborn rats and mice, as compared with their adult counterparts, relates, in part, to the greater amount of triglyceride in the lipid fraction of the newborn compared with the adult lung (13). Kehrer and Autor (11) demonstrated that increasing the saturated fatty acid composition of lung triglycerides in adult rats by dietary manipulation produced increased susceptibility to oxygen toxicity. Feeding pregnant rats a high triglyceride diet results in increased triglyceride content in the lungs of their offspring and increased survival and improved clinical and pathologic status after prolonged hyperoxic exposure (14, 15).

The mechanism responsible for this tolerance to hyperoxia has been speculated by Dormandy (16) to relate to the role of neutral lipids as antioxidants, which would confer protection against oxygen and oxygen free radical injury.

Studies from our laboratory have determined that, during fetal lung development, triglyceride uptake and content are 
dependent on gestational age (17), sex (18), hormonal milieu (19), and nutritional status in vitro (17). Therefore, we hypothesized that the biologic variability in lung antioxidant capacity is dependent on quantitative differences in fetal lung fibroblast triglyceride content at the time of exposure to $\mathrm{H}_{2} \mathrm{O}_{2}$ as a function of gestational age (18 to $21 \mathrm{~d}$ gestation), triglyceride exposure $(0-20 \%)$, or hormonal treatment (dexamethasone or dihydrotestosterone).

\section{METHODS}

Isolation of FRLFs. Five to 10 time-mated rat dams were used per preparation depending on the number of experimental variables to be tested. Isolation of FRLFs was performed according to methods of Smith and Giroud (20) as follows. The fetal lungs were removed into Hanks' balanced salt solution. The Hanks' balanced salt solution was decanted, and 5 vol of $0.05 \%$ trypsin was added to the lung preparation. The lungs were dissociated in a $37^{\circ} \mathrm{C}$ water bath using a Teflon stirring bar to disrupt the tissue mechanically. Once the tissue was dispersed into a unicellular suspension (approximately 20 $\mathrm{min}$ ), the cells were pelleted at $500 \times \mathrm{g}$ for $10 \mathrm{~min}$ at room temperature in a $50-\mathrm{mL}$ polystyrene centrifuge tube. The supernatant was decanted, and the pellet was resuspended in DMEM, containing $20 \% \mathrm{FCS}$, to yield a mixed cell suspension of approximately $3 \times 10^{8}$ cells, as determined by Coulter particle counter (Beckman-Coulter, Hialeah, FL, U.S.A.). The cell suspension was then added to culture flasks $\left(80 \mathrm{~cm}^{2}\right)$ for $30-60 \mathrm{~min}$ to allow for differential adherence of lung fibroblasts. These cells are $>95 \%$ pure fibroblasts based on vimentin-positive staining.

Treatment of animals and cultured cells with hormones and lipids. These methods have previously been described (17, 19). Briefly, fibroblast cultures were incubated with a rat serum triglyceride fraction at the indicated concentrations on a vol/vol basis (21). All animal experimentation was approved by the Institutional Review Board of the Harbor-UCLA Research and Education Institute.

Cell viability assays. The method used was based on the method of Spitz et al. (22) with minor modification. Briefly, fibroblast cultures were treated with $\mathrm{H}_{2} \mathrm{O}_{2}(0.1-1.0 \mathrm{mM})$ for 5 min at $37^{\circ} \mathrm{C}$, during which time there was a linear doseresponse relationship between $\mathrm{H}_{2} \mathrm{O}_{2}$ concentration and cell viability, in an atmosphere of $5 \% \mathrm{CO}_{2}$, balance air. At the end of the incubation, the $\mathrm{H}_{2} \mathrm{O}_{2}$ was aspirated, and the cultures were washed three times with DMEM; the surviving cells were cultured for $24 \mathrm{~h}$ in DMEM/10\% FCS. At the end of the recovery period, the surviving cells were removed with $0.1 \%$ trypsin, and an aliquot was counted in a Coulter particle counter.

Triglyceride assay. The cellular levels of triglyceride were determined as previously described (17).

Lipid peroxidation assay. Lipid peroxidation products, MDA and 4HNE, were assayed using a colorimetric assay (Calbiochem, La Jolla, CA, U.S.A.). Briefly, after the experimental conditions, cells were lysed by repetitive freezing and thawing in distilled water. Samples were diluted in $20 \mathrm{mM}$ Tris-HCl, pH 7.4. Diluted sample (200 $\mu \mathrm{L})$ was added to 650 $\mu \mathrm{L}$ of diluted reagent, $10.3 \mathrm{mM} \mathrm{N}$-methyl-2-phenylindole in acetonitrile, in a glass test tube. The mixture was vortexed for 3-4 s, and MDA and 4HNE were assayed by adding $150 \mu \mathrm{L}$ of 15.4 M methanesulfonic acid. The solution was mixed well and incubated at $45^{\circ} \mathrm{C}$ for $40 \mathrm{~min}$, after which samples were allowed to cool on ice. The samples were centrifuged at 10,000 $\times g$ for $5 \mathrm{~min}$, and light absorbance was measured at $586 \mathrm{~nm}$. Standard curves for MDA and 4HNE were generated as per the manufacturer's protocol, and the concentrations of MDA and 4HNE were calculated based on the extinction coefficients calculated from the standard curves.

GSH assay. Reduced GSH was assayed using a colorimetric assay (Calbiochem). Briefly, after the experimental conditions, cells were lysed and suspended in $500 \mu \mathrm{L}$ of freshly prepared $5 \%$ metaphosphoric acid. Cells were homogenized with a Teflon pestle, and the homogenate was centrifuged at $3000 \times$ $g$ for $10 \mathrm{~min}$ at $4^{\circ} \mathrm{C}$. Twenty to three hundred microliters of the resultant homogenate was used for the GSH assay. The total volume was made up to $900 \mu \mathrm{L}$ with buffer composed of 200 $\mathrm{mM}$ potassium phosphate, $\mathrm{pH} 7.8$, containing $0.2 \mathrm{mM}$ diethylene triamine pentaacetic acid and $0.025 \%$ Lubrol (Calbiochem). Then $50 \mu \mathrm{L}$ of a $12 \mathrm{mM}$ solution of 4-chloro-1-methyl7-fluoromethyl-quinolinium methylsulfate in $0.2 \mathrm{~N} \mathrm{HCl}$ was added, and the solution was mixed thoroughly. After this, 50 $\mu \mathrm{L}$ of $30 \% \mathrm{NaOH}$ was added, followed by thorough mixing, and the solution was incubated at $25^{\circ} \mathrm{C}$ for $10 \mathrm{~min}$ in the dark. Final absorbance was measured at $400 \mathrm{~nm}$. Standard curves for GSH were generated according to the manufacturer's protocol, and the concentrations of GSH in the samples were calculated from their absorbance.

Statistical analysis. Student's $t$ test or ANOVA for multiple comparisons was used to analyze the experimental data, as indicated.

\section{RESULTS}

Bio-dependent differences in fibroblast triglyceride content. We initially analyzed FRLFs for their triglyceride content as a function of 1) gestational age, 2) sex, 3) hormonal exposure, and 4) nutrition (Fig. 1). The triglyceride content of d 21 FRLFs was $112 \%$ higher than the triglyceride content of d 19 FRLFs. A similar difference in triglyceride content was observed when sex-specific FRLFs from d 20 fetal males and females were analyzed $\left(108 \pm 32\right.$ versus $202 \pm 26 \mu \mathrm{g} / 10^{6}$ cells, respectively). In vivo treatment of d 20 fetal rats with DHT $(1 \mathrm{mg} / \mathrm{kg}$ for $48 \mathrm{~h}$ ) decreased the triglyceride content of FRLFs by $70 \%$, and DEX $(0.25 \mathrm{mg} / \mathrm{kg}$ for $24 \mathrm{~h})$ increased it by $30 \%$, resulting in a 2.5 -fold difference between these two groups. Treatment with both DHT and DEX resulted in triglyceride content of FRLFs that was the same as for DHT treatment alone, indicating DHT inhibition of the DEX effect on triglyceride uptake by these cells. Furthermore, the triglyceride content of d 19 FRLFs was determined by the serum triglyceride content of the medium in which the cells were cultured (exposure to $0 \%, 2 \%, 10 \%$, or $20 \%$ serum triglyceride resulted in mean fibroblast triglyceride contents of $97 \pm 23$, $104 \pm 38,158 \pm 40$, and $210 \pm 44 \mu \mathrm{g} / 10^{6}$ cells, respectively). 


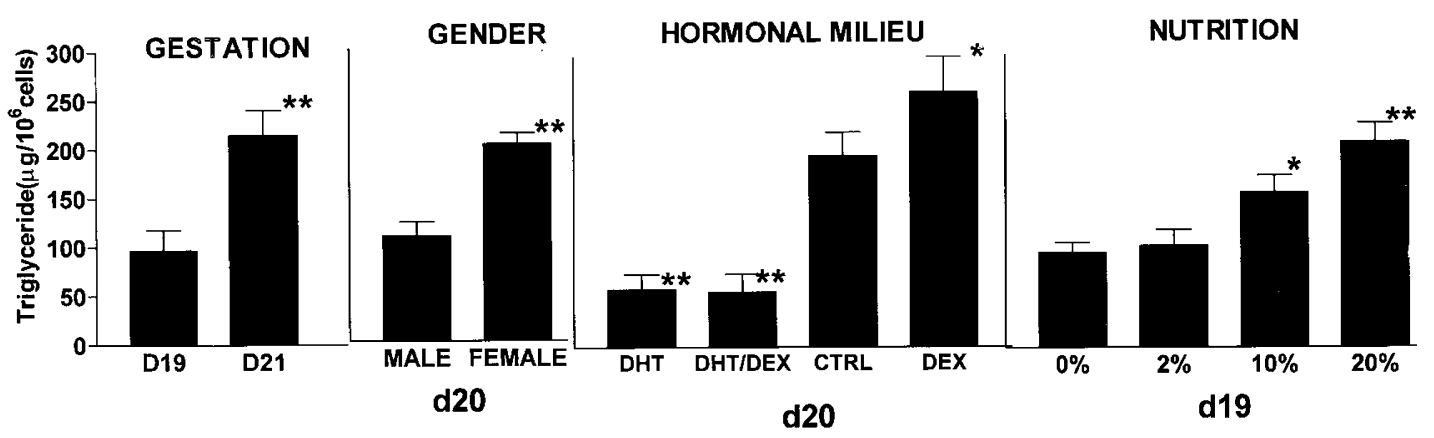

Figure 1. Biovariabilily in FRLF triglyceride content. FRLFs were harvested from the indicated groups and analyzed for their triglyceride content. Groups (from left to right): gestational age, d19 versus $\mathrm{d} 21$; gender, d20 male and female fetuses; hormonal milieu, d20 pregnant rats treated with DEX (0.25 mg/kg s.c.), DHT ( $1 \mathrm{mg} / \mathrm{kg}$ s.c.), or DHT and DEX (DHT/DEX), or controls (CTRL); nutrition, d19 fibroblasts incubated with $0 \%, 2 \%, 10 \%$, or $20 \%$ serum triglyceride for $24 \mathrm{~h}$. Each bar represents the mean $\pm \mathrm{SD}$ of three to five experiments $(n=12-20) .{ }^{*} p<0.05 ; * * p<0.01, \mathrm{~d} 19$ versus $\mathrm{d} 21$; d20 male versus female; DHT, DHT/DEX, DEX versus CTRL, $2 \%, 10 \%, 20 \%$ versus $0 \%$, respectively, by ANOVA for multiple comparisons.

FRLF viability versus gestational age. Having established that there were significant differences in FRLF triglyceride content depending on gestational age (d 19 versus $\mathrm{d} 21)$, we tested the effect of gestational age on resistance to $\mathrm{H}_{2} \mathrm{O}_{2}$ injury. As can be seen in Figure 2, there was a significant difference in response to $\mathrm{H}_{2} \mathrm{O}_{2}$ exposure between $\mathrm{d} 18$ and $\mathrm{d} 21$ FRLFs at the 0.5 and $1.0 \mathrm{mM}$ concentrations $(54 \%$ versus $97 \%, p<$ $0.001 ; 8 \%$ versus $72 \%, p<0.001 ; \mathrm{d} 18$ versus $\mathrm{d} 21$, respectively). Incubation of d 18 FRLFs with serum triglyceride, $20 \%$ for $24 \mathrm{~h}$, increased survival of the d 18 cells significantly at both the 0.5 and $1.0 \mathrm{mM} \mathrm{H}_{2} \mathrm{O}_{2}$ doses (54\% versus $75 \%, p<$ $0.001 ; 8 \%$ versus $57 \%, p<0.001 ; \mathrm{d} 18$ versus $\mathrm{d} 18$ with serum triglyceride, respectively), approaching the $\mathrm{d} 21$ FRLF survival rate at the $1 \mathrm{mM} \mathrm{H}_{2} \mathrm{O}_{2}$ exposure level.

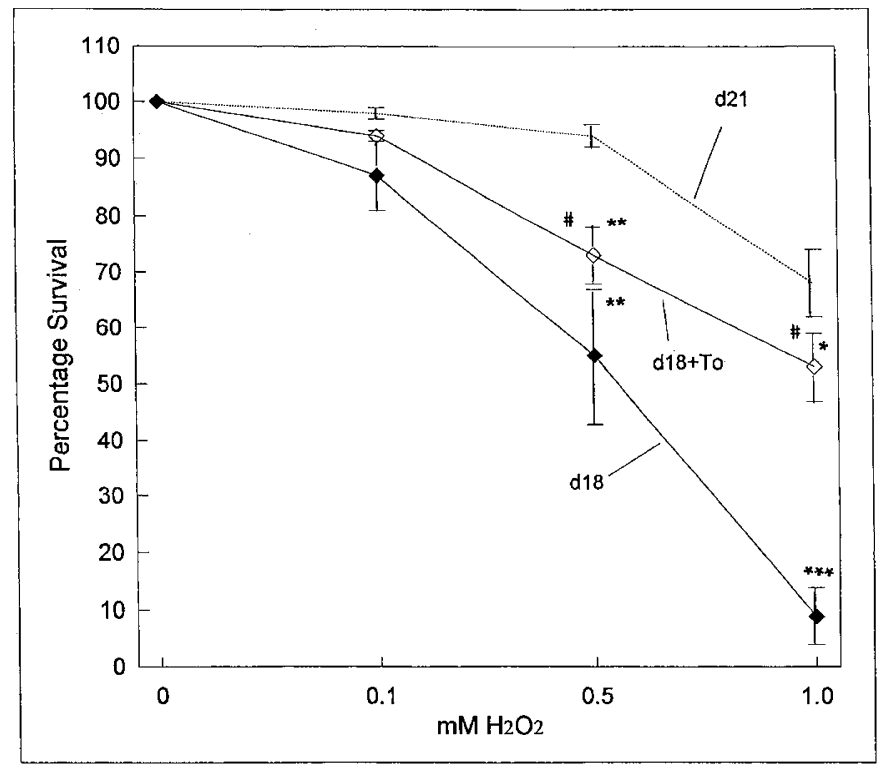

Figure 2. Effect of gestational age on fibroblast resistance to $\mathrm{H}_{2} \mathrm{O}_{2}$. Confluent cultures of d 18 and d 21 FRLFs were challenged with $\mathrm{H}_{2} \mathrm{O}_{2}$ for $5 \mathrm{~min}$, and the number of surviving cells was determined $24 \mathrm{~h}$ later. d18 + To, d 18 fibroblasts preincubated with $20 \%$ serum triglycerides for $24 \mathrm{~h}$. Each value is the mean $\pm \mathrm{SD}$ of three experiments $(n=15) .{ }^{*} p<0.05 ;{ }^{* *} p<0.001 ; * * * p$ $<0.0001$ versus $\mathrm{d} 21$; and \# comparison of $\mathrm{d} 18$ and $\mathrm{d} 18+$ To groups by ANOVA for multiple comparisons.
FRLF viability versus gender. Day 20 FRLFs from male and female fetuses were preincubated with serum triglyceride $(0 \%, 2 \%, 10 \%$, or $20 \%$ for $24 \mathrm{~h})$ and subsequently exposed to $0.5 \mathrm{mM} \mathrm{H}_{2} \mathrm{O}_{2}$ for $5 \mathrm{~min}$ (Fig. 3). Among the male FRLF group there was a significant difference in survival between the $0 \%$ versus $20 \%$ groups $(26 \%$ versus $82 \%, p<0.02)$. The viability rates among the female FRLF group were not statistically different, although at the $0 \%, 2 \%$, and $10 \%$ serum triglyceride exposures they were significantly higher than the males $(30 \%$ versus $65 \%$; $48 \%$ versus $81 \%$; $69 \%$ versus $93 \%$, male versus female, respectively; $p<0.02$ ).

FRLF viability versus hormonal exposure. FRLFs from d 21 fetuses treated with DHT in utero $(1 \mathrm{mg} / \mathrm{kg} / \mathrm{d}$ for $48 \mathrm{~h})$ were markedly sensitized to $\mathrm{H}_{2} \mathrm{O}_{2}$ exposure at $0.1,0.5$, and $1.0 \mathrm{mM}$ $\mathrm{H}_{2} \mathrm{O}_{2}(52 \%$ versus $98 \%, p<0.01 ; 12 \%$ versus $96 \%, p<$ $0.001 ; 6 \%$ versus $71 \%, p<0.001 ;$ DHT versus control,

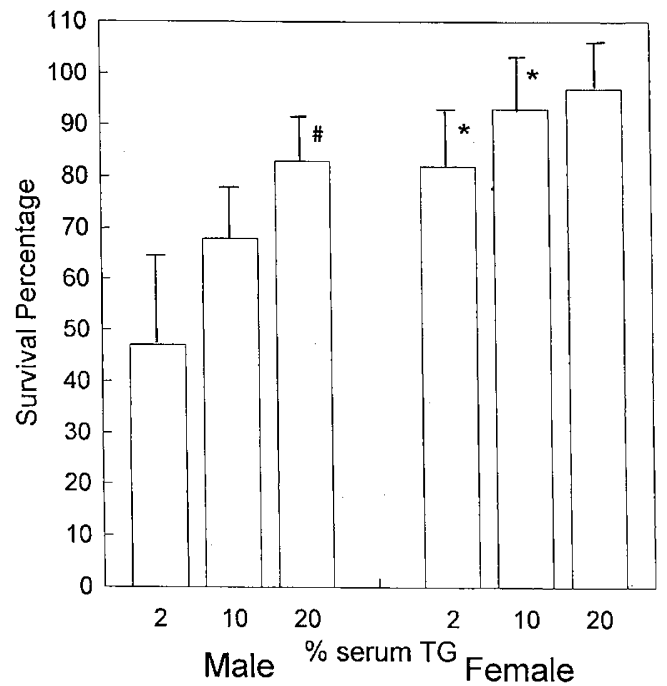

Figure 3. Effect of sex on fibroblast resistance to $\mathrm{H}_{2} \mathrm{O}_{2}$. Day 20 male and female FRLFs were preincubated with serum triglycerides (TG; $0 \%, 2 \%$, $10 \%, 20 \%$ ) for $24 \mathrm{~h}$ and subsequently exposed to $0.5 \mathrm{mM} \mathrm{H}_{2} \mathrm{O}_{2}$ for $5 \mathrm{~min}$. The number of surviving cells was determined $24 \mathrm{~h}$ later. Each bar represents the mean $\pm \mathrm{SD}$ of three experiments $(n=15)$. $\# p<0.05 ; 20 \%$ versus $0 \%$ male group; ${ }^{*} p<0.05$, female versus male by ANOVA for multiple comparisons. 
respectively; Fig. 4). Day 18 survival data are provided for comparison. Conversely, DEX treatment $(0.25 \mathrm{mg} / \mathrm{kg}$ for $24 \mathrm{~h})$ significantly increased the survival of $d 18$ FRLFs at the 0.5 and $1.0 \mathrm{mM} \mathrm{H}_{2} \mathrm{O}_{2}$, exposures ( $54 \%$ versus $74 \%, p<0.05 ; 8 \%$ versus $53 \%, p<0.001 ; \mathrm{d} 18$ versus $\mathrm{d} 18+\mathrm{DEX}$, respectively; Fig. 5). A 24-h exposure to serum triglyceride (20\%) further enhanced the survival of DEX-treated d 18 FRLFs, making them comparable to d 21 control rats.

Direct effect of DEX and DHT on FRLF viability in response to $\mathrm{H}_{2} \mathrm{O}_{2}$. To directly test the effects of DEX and DHT on FRLF viability, d 19 fibroblasts were treated with DEX (1 $\left.\times 10^{-8} \mathrm{M}\right)$ or DEX + DHT $\left(1 \times 10^{-8} \mathrm{M}\right.$ and $1 \times 10^{-7} \mathrm{M}$, respectively) for $24 \mathrm{~h}$ (Fig. 6). Steroid treatment per se had no effect on cell survival. In contrast to this, an additional 15 -h exposure to $10 \%$ serum triglyceride resulted in a significant difference between control and DEX-treated cells, which was blocked by DHT (control, 58\% versus DEX, 97\%; $p<0.01$; DEX + DHT, 62\%), thus providing evidence that the steroid effect on antioxidant function is triglyceride-dependent.

FRLF viability versus nutrition. Day 19 FRLFs were incubated with serum triglycerides $(2 \%, 10 \%, 20 \%$ for $24 \mathrm{~h})$ and exposed to graded doses of $\mathrm{H}_{2} \mathrm{O}_{2}$ for $5 \mathrm{~min}$. There were significant differences in percent survival between the $2 \%$ and $20 \%$ serum-exposed groups at the 0.5 and $1.0 \mathrm{mM} \mathrm{H}_{2} \mathrm{O}_{2}$ exposures $(71 \%$ versus $97 \%, p<0.05 ; 29 \%$ versus $71 \%, p<$ 0.001 , respectively; Fig. 7). The $10 \%$ serum-exposed group fell between the $20 \%$ and $2 \%$ serum-exposed groups, exhibiting a significant difference versus the $20 \%$ serum-exposed group only at the $1.0 \mathrm{mM} \mathrm{H}_{2} \mathrm{O}_{2}$ exposure $(49 \%$ versus $69 \%, p<$ $0.01)$.

GSH and lipid peroxidation status and FRLF viability. Day 19 fibroblasts were incubated with serum triglycerides $(2 \%$, $10 \%, 20 \%)$, DEX $\left(1 \times 10^{-8} \mathrm{M}\right)$, DHT $\left(1 \times 10^{-7} \mathrm{M}\right)$, or DEX + DHT $\left(1 \times 10^{-8} \mathrm{M}\right.$ and $1 \times 10^{-7} \mathrm{M}$, respectively $)$ for $24 \mathrm{~h}$. Fibroblasts were subsequently exposed to $\mathrm{H}_{2} \mathrm{O}_{2}(0.1-1.0 \mathrm{mM} / 5$ $\mathrm{min})$. GSH content and lipid peroxidation status were determined at baseline and in the surviving cells after $\mathrm{H}_{2} \mathrm{O}_{2}$ expo-

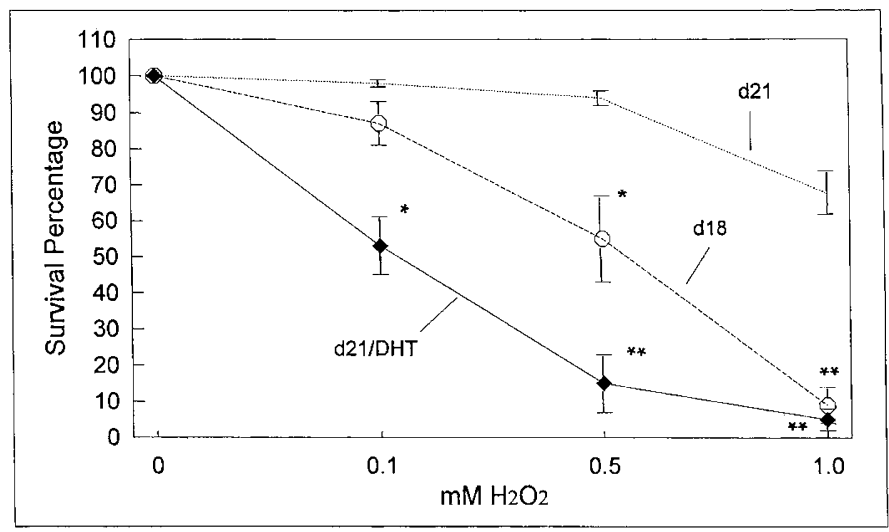

Figure 4. Effect of in vivo DHT exposure on fibroblast resistance to $\mathrm{H}_{2} \mathrm{O}_{2}$. Pregnant rats were treated with DHT $(1 \mathrm{mg} / \mathrm{kg} / \mathrm{d}$ for $2 \mathrm{~d})$, and fibroblasts were harvested on $\mathrm{d} 21$ (d2I/DHT). Confluent cultures were exposed to graded doses of $\mathrm{H}_{2} \mathrm{O}_{2}$ for $5 \mathrm{~min}$, and the number of surviving cells was determined $24 \mathrm{~h}$ later. Survival of d 18 fibroblasts is shown for comparison (d18). Each data point represents the mean $\pm \mathrm{SD}$ of three experiments $(n=15) .{ }^{*} p<0.01 ; * * p$ $<0.001$ versus $\mathrm{d} 21$ control by ANOVA for multiple comparisons.

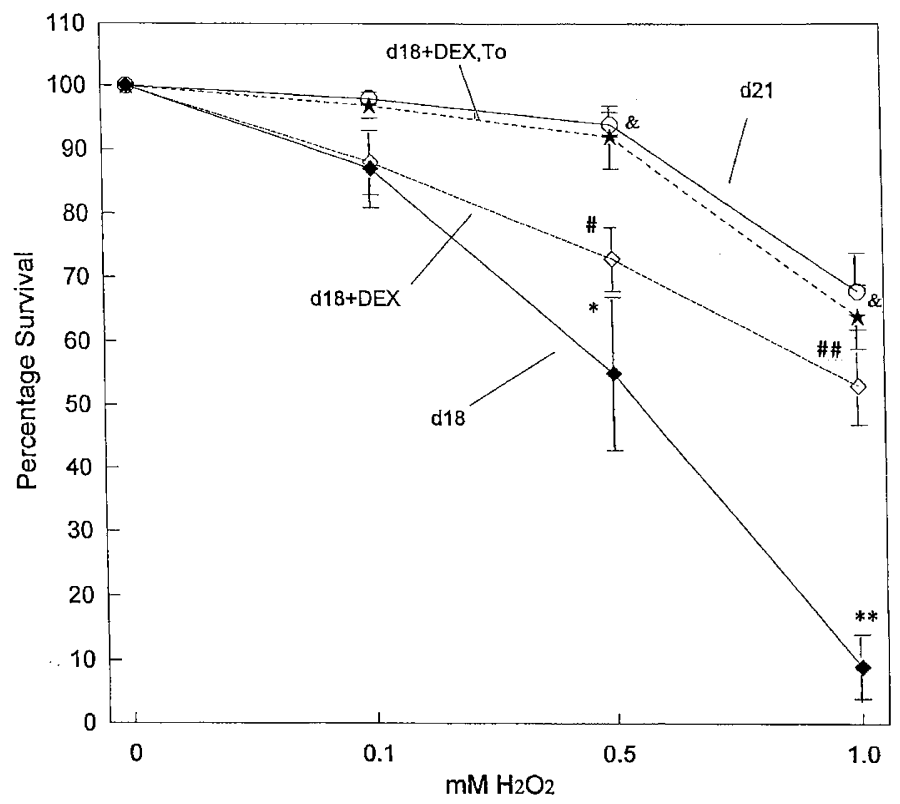

Figure 5. Effect of in vivo DEX exposure on fibroblast resistance to $\mathrm{H}_{2} \mathrm{O}_{2}$. Pregnant rats were treated with DEX $(0.25 \mathrm{mg} / \mathrm{kg} / \mathrm{d}$ for $24 \mathrm{~h})$, and fibroblasts were harvested on d 18 (d18 + DEX). Day 18 fibroblasts were also incubated with serum triglycerides $(20 \% / 24 \mathrm{~h}$; d18 + DEX, To). Cells were exposed to $\mathrm{H}_{2} \mathrm{O}_{2}$ at the doses indicated for $5 \mathrm{~min}$. Day 18 and 21 control data are shown for comparison. Each data point represents the mean $\pm \mathrm{SD}$ of three experiments $(n=15) . * p<0.01 ; * * p<0.001$, d18 versus $\mathrm{d} 21 ; \# p<0.02 ; \# p<$ $0.05, \mathrm{~d} 18+$ DEX versus $\mathrm{d} 21 ; \& p>0.05 \mathrm{~d} 18+$ DEX, To versus $\mathrm{d} 21$, by ANOVA for multiple comparisons.

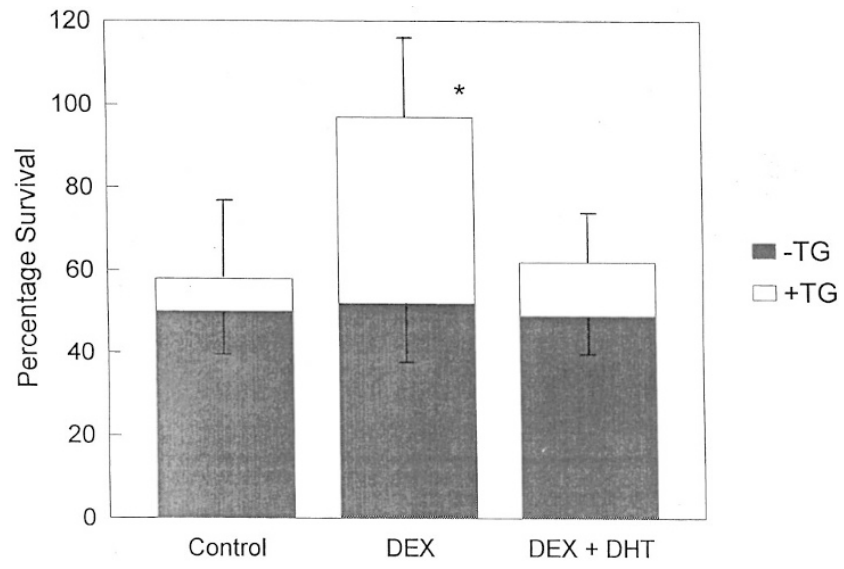

Figure 6. Effect of in vitro DEX and DHT exposure on fibroblast resistance to $\mathrm{H}_{2} \mathrm{O}_{2}$. Cultured d 19 fibroblasts were treated with DEX $\left(1 \times 10^{-8} \mathrm{M}\right)$ or DEX + DHT $\left(1 \times 10^{-8} \mathrm{M}, 1 \times 10^{-7} \mathrm{M}\right.$, respectively $)$ for $24 \mathrm{~h}$ and subsequently treated with $10 \%$ serum triglyceride (TG) for $15 \mathrm{~h}$. The cells were then exposed to $1 \mathrm{mM} \mathrm{H}_{2} \mathrm{O}_{2}$ for $5 \mathrm{~min}$ and assayed for cell survival $24 \mathrm{~h}$ later. Each bar represents the mean $\pm \mathrm{SD}$ of three experiments $(n=15) .{ }^{*} p<0.01$, DEX versus control by $t$ test.

sure. The number of surviving cells was determined, and the GSH content and lipid peroxidation status were corrected for the differences in the number of surviving cells. There were no differences in either GSH content or lipid peroxidation status at baseline in different serum- and hormone-treated groups (Figs. 8 and 9). GSH content significantly decreased after $\mathrm{H}_{2} \mathrm{O}_{2}$ exposure (at 0.5 and $1 \mathrm{mM}$, but not at $0.1 \mathrm{mM} \mathrm{H}_{2} \mathrm{O}_{2}$ exposure) in some serum- $(2 \%)$ and hormone- (DHT) treated groups. Lipid peroxidation increased significantly in all serum- and 


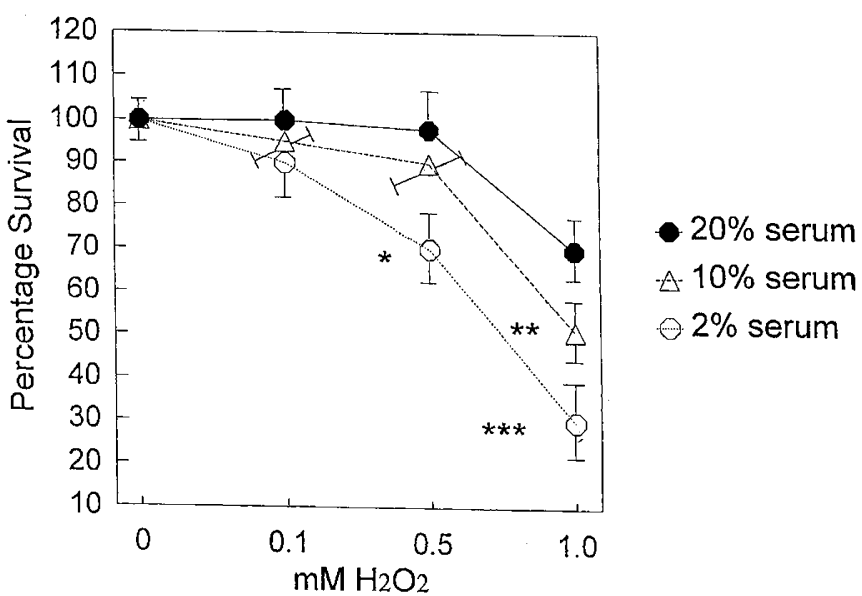

Figure 7. Effect of triglyceride loading on fibroblast survival in response to $\mathrm{H}_{2} \mathrm{O}_{2}$. Day 19 fibroblasts were incubated with serum triglycerides $(2 \%, 10 \%$, $20 \%$ ) for $24 \mathrm{~h}$ and subsequently exposed to $\mathrm{H}_{2} \mathrm{O}_{2}(0.1-1.0 \mathrm{mM} / 5 \mathrm{~min})$. The number of surviving cells was determined $24 \mathrm{~h}$ later. Each data point represents the mean $\pm \mathrm{SD}$ of five experiments $(n=20) .{ }^{*} p<0.05 ; * * p<0.01 ; * * * p$ $<0.001$ versus $20 \%$ serum group by ANOVA for multiple comparisons. hormone-treated groups in a dose-dependent manner corresponding to the concentration of $\mathrm{H}_{2} \mathrm{O}_{2}$ exposure. However, there was evidence of increased peroxidation in the $2 \%$ serumsupplemented group versus the $10 \%$ and $20 \%$ supplemented groups. Furthermore, the DEX-treated group showed somewhat decreased lipid peroxidation versus DHT and DEX + DHT-treated groups.

\section{DISCUSSION}

In the present series of studies, we have demonstrated that during fetal rat lung development there are significant differences in the triglyceride content of fibroblasts because of gestation, sex, hormonal milieu, and nutrition. More important, these differences in the triglyceride content of the developing lung fibroblast result in significant differences in the viability of these cells on exposure to $\mathrm{H}_{2} \mathrm{O}_{2}$, which is one of several reactive oxygen species that mediate the biologic effects of hyperoxia (23). These differences were observed in the presence of similar baseline GSH content in different nutritional
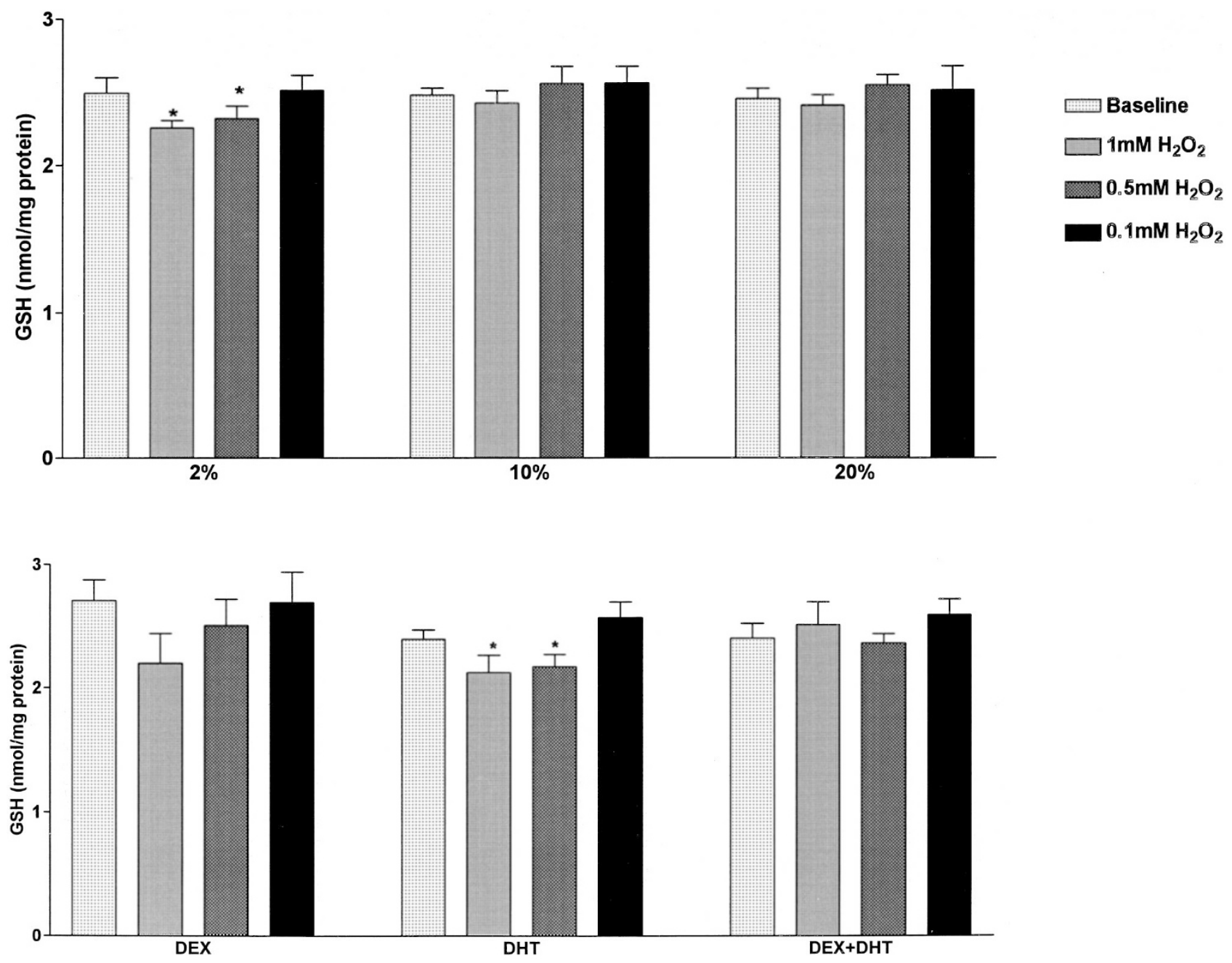

Figure 8. Effect of triglyceride loading and hormonal exposure on reduced GSH status at baseline and after exposure to $\mathrm{H}_{2} \mathrm{O}_{2}$. Day 19 fibroblasts were incubated with serum triglycerides $(2 \%, 10 \%, 20 \%$; Top $)$, DEX $\left(1 \times 10^{-8} \mathrm{M}\right)$, DHT $\left(1 \times 10^{-7} \mathrm{M}\right)$, or DEX + DHT $\left(1 \times 10^{-8} \mathrm{M}, 1 \times 10^{-7} \mathrm{M}\right.$, respectively; Bottom $)$ for $24 \mathrm{~h}$ and subsequently exposed to $\mathrm{H}_{2} \mathrm{O}_{2}(0.1-1.0 \mathrm{mM} / 5 \mathrm{~min})$. GSH status was determined at baseline and in the surviving cells after $\mathrm{H}_{2} \mathrm{O}_{2}$ exposure. The number of surviving cells was determined, and the GSH status was corrected for the differences in the number of surviving cells in each group. Each bar represents the mean $\pm \mathrm{SD}$ of three experiments $(n=9) .{ }^{*} p<0.05$ versus baseline. 

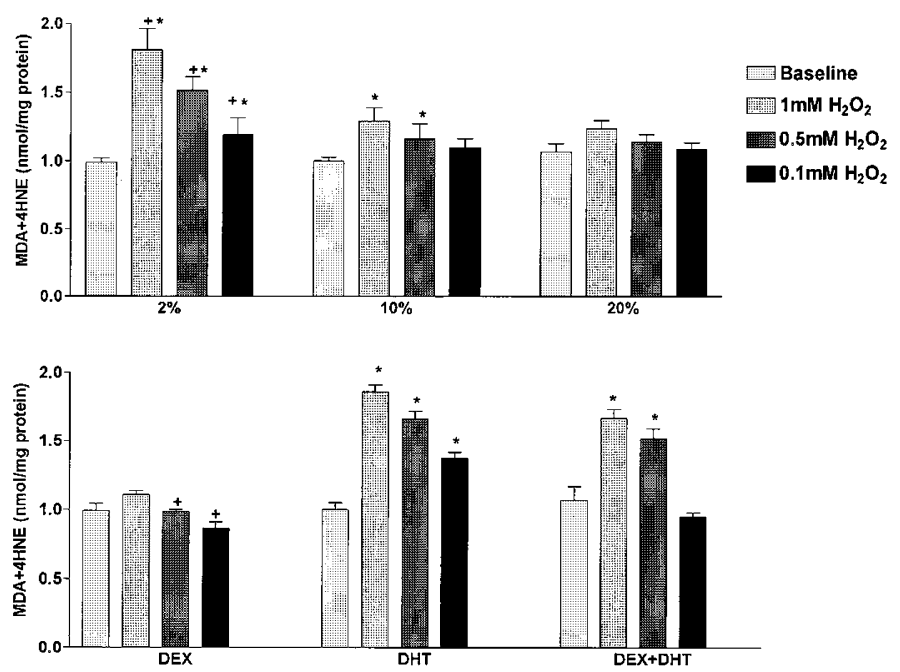

Figure 9. Effect of triglyceride loading and hormonal exposure on lipid peroxidation status at baseline and after exposure to $\mathrm{H}_{2} \mathrm{O}_{2}$. Day 19 fibroblasts were incubated with serum triglycerides $(2 \%, 10 \%, 20 \%$; Top $)$, DEX $(1 \times$ $\left.10^{-8} \mathrm{M}\right)$, DHT $\left(1 \times 10^{-7} \mathrm{M}\right)$, or DEX + DHT $\left(1 \times 10^{-8} \mathrm{M}, 1 \times 10^{-7} \mathrm{M}\right.$, respectively; Bottom) for $24 \mathrm{~h}$ and subsequently exposed to $\mathrm{H}_{2} \mathrm{O}_{2}(0.1-1.0$ $\mathrm{mM} / 5 \mathrm{~min}$ ). Lipid peroxide (MDA + 4HNE) status was determined at baseline and in the surviving cells after $\mathrm{H}_{2} \mathrm{O}_{2}$ exposure. The number of surviving cells was determined, and the peroxidation status was corrected for the differences in the number of surviving cells in each group. Each bar represents the mean $\pm \mathrm{SD}$ of three experiments $(n=9) .{ }^{*} p<0.05$ versus baseline and $+p<0.05$ for $2 \%$ versus $20 \%$ by ANOVA for multiple comparisons.

(triglyceride) categories. The lipid-dependence of this relationship is demonstrated by the independent effects of fibroblast lipid stores (owing to either gestational age, sex, lipid exposure, or the hormonal effects of DEX and DHT) on cell viability in response to $\mathrm{H}_{2} \mathrm{O}_{2}$ exposure. The experimental rationale for using fibroblasts at selected gestational ages (18-21 d) was based on both their endogenous triglyceride stores (17) and their ability to respond to glucocorticoid stimulation (19) and androgen inhibition (18) of triglyceride uptake. Notably, the effects of both stimulatory (DEX) and inhibitory (DHT) steroids on cell viability in response to $\mathrm{H}_{2} \mathrm{O}_{2}$ were only observed after the cells were incubated with serum triglycerides, suggesting that the cytoprotection was caused by the hormonal effect on triglyceride content of the cells. These hormonal effects may determine the developmental and sexspecific differences in fibroblast triglyceride content inasmuch as glucocorticoids regulate this mechanism developmentally (19) and androgens act as antiglucocorticoids $(18,24,25)$, delaying glucocorticoid-dependent fibroblast maturation (25). Thus, hormonal regulation of fibroblast triglyceride metabolism provides a plausible mechanism for the observed biovariability in response to $\mathrm{H}_{2} \mathrm{O}_{2}$ treatment.

The biologic basis for differences in susceptibility to hyperoxia remains highly controversial. The primary physiologic mechanism by which tissues inactivate oxygen free radicals is dependent on the activities of the AOEs, such as superoxide dismutase, catalase, and the GSH system, which consists of a battery of enzymes (26). In the lung, these enzymes appear during late gestational development (27) and are stimulated by glucocorticoids (28), making them good candidates for a developmentally dependent, hormonally regulated antioxidant mechanism. However, there are a number of biologic conditions under which there are differences in response to oxygen that cannot be explained on the basis of differences in AOE activities. For example, there is a sex difference in the incidence of bronchopulmonary dysplasia (29), but there is no sex difference in the rate of AOE maturation (7). Similarly, there are age (30) and species (30) differences in susceptibility to oxidant injury that are unaccounted for on the basis of the AOE mechanism (31). Our data further reinforce this assertion because we observed significant differences in cell survival in response to $\mathrm{H}_{2} \mathrm{O}_{2}$ exposure in the absence of any differences in the baseline GSH status in various serum- and hormone-treated categories. However, inasmuch as we did not measure all of the AOEs of the antioxidant system, including superoxide dismutase and catalase, it is possible that some of the biovariability in response to hyperoxia may be governed by differences in the status of AOEs that were not determined. However, the observation of a lack of any differences in AOE (superoxide dismutase, catalase, and GSH peroxidase) status in the offspring of high- and low-polyunsaturated fatty acid-supplemented rats despite the observed differences in tolerance to hyperoxia (15) concurs with our observations.

In contrast to the lack of correlation between protection against hyperoxia and AOE mechanisms, there does appear to be a good fit with fibroblast triglyceride metabolism and content. For example, we have demonstrated that there is a significant sex difference in the uptake and content of triglyceride in fetal lung fibroblasts, which results in a quantitative difference in the response to $\mathrm{H}_{2} \mathrm{O}_{2}$ treatment. These data are consistent with the observation by Neriishi and Frank (32) that there is a sex difference in response to hyperoxia by adult rats that is eliminated by castration and reinstated by androgen treatment. Similarly, there are well-documented species differences - neonatal rats, rabbits, and mice are more resistant to hyperoxia than are guinea pigs and hamsters (30). These species differences in response to hyperoxia cannot be accounted for by differences in AOEs (33); however, in studies performed by Kaplan et al. (34) on species differences in the lipid content of lung lipofibroblasts it was observed that rat lung lipofibroblasts contain considerably more lipid than do those derived from hamsters. These observations are consistent with our hypothesized role of cellular lipids as cytoprotective agents.

Glucocorticoids have a well-documented effect on protecting the neonatal lung from oxidant injury (29). Steroids have been shown to accelerate maturation of the lung AOE mechanism and reduce oxidant injury $(28,35)$, consistent with their role in cytoprotection. In the current study, glucocorticoids were shown to also increase the triglyceride content of FRLFs and to decrease the cellular toxicity caused by $\mathrm{H}_{2} \mathrm{O}_{2}$ injury despite any effect on their glutathione content. However, the effect of DEX on antioxidant activity was only observed after the cells were exposed to triglyceride, further suggesting that the effect of cytoprotection in the steroid-treated group is related to differences in the triglyceride content rather than to the GSH status of these cells. The baseline GSH content of DEX-treated cells and untreated cells was similar, further suggesting that the effect of cytoprotection in the steroid- 
treated group is related to differences in the triglyceride content rather than in the GSH status. Similarly, DHT antagonized the DEX effect on cell viability, but only after exposure of the cells to triglyceride. Undoubtedly, the cytoprotection from oxidant injury is a complex process, and we did not explore the underlying specific cellular and molecular mechanisms. From the data presented, however, we conclude that the hormonal effect on FRLFs is not on constitutive AOEs but on the ability of these cells to metabolize triglycerides.

\section{REFERENCES}

1. Roberts RJ 1984 Pulmonary oxygen toxicity in the premature and full term infant: its relationship to the development and pathogenesis of RDS and of its complications. In: Stern L (ed) Hyaline Membrane Disease Pathogenesis and Pathophysiology. Grune and Stratton, Orlando, pp 211-232

2. Van Marter LJ, Leviton A, Kuban KCK, Pagano M, Allred EN 1990 Maternal glucocorticoid therapy and reduced risk of bronchopulmonary dysplasia. Pediatrics $86: 331-336$

3. National Institutes of Health 1994 The effect of corticosteroids for fetal maturation and perinatal outcomes. National Institutes of Health Consensus Statement 12:1-24

4. Frank L, Sosenko IRS 1988 Undernutrition as a major contributing factor in the pathogenesis of bronchopulmonary dysplasia. Am Rev Respir Dis 138:725-729

5. Chen Y, Whitney PL, Frank L 1994 Comparative responses of premature versus full-term newborn infant rats to prolonged hyperoxia. Pediatr Res 35:233-237

6. Frank L, Autor AP, Roberts RJ 1992 Oxygen therapy and hyaline membrane disease: the effect of hyperoxia on pulmonary superoxide dismutase activity and the mediating role of plasma or serum. J Pediatr 90:105-110

7. Sosenko IR, Nielsen HC, Frank L 1989 Lack of sex differences in antioxidant enzyme development in the fetal rabbit lung. Pediatr Res 26:16-19

8. Hart CM, Tolson JK, Block ER 1991 Supplemental fatty acids alter lipid peroxidation and oxidant injury in endothelial cells. Am J Physiol 260:L481-L488

9. Dennery PA, Kramer CM, Alpert SE 1990 Effect of fatty acid profiles on the susceptibility of cultured rabbit tracheal epithelial cells to hyperoxic injury. Am J Respir Cell Mol Biol 3:137-144

10. Spitz DR, Kinter MT, Kehrer JP, Roberts RJ 1992 The effects of monounsaturated and polyunsaturated fatty acids on oxygen toxicity in cultured cells. Pediatr Res 32:366-372

11. Kehrer JP, Autor AP 1978 The effect of dietary fatty acids on the composition of adult rat lung lipids: relationship to oxygen toxicity. Toxicol Appl Pharmacol 44:423-440

12. Block ER 1988 Interaction between oxygen and cell membranes: modification of cell membrane lipids to enhance pulmonary artery endothelial cell tolerance to hyperoxia. Exp Lung Res 14:937-958
13. Yam J, Frank L, Roberts R 1998 Oxygen toxicity: comparison of lung biochemical responses in neonatal and adult rats. Pediatr Res 12:115-119

14. Sosenko IRS, Innis SM, Frank L 1989 Menhaden fish oil, n-3 polyunsaturated fatty acids and protection of newborn rats from oxygen toxicity. Pediatr Res 25:399-404

15. Sosenko IRS, Innis SM, Frank L 1991 Intralipid increases lung polyunsaturated fatty acids and protects newborn rats from oxygen toxicity. Pediatr Res 30:413-417

16. Dormandy TL 1969 Biologic rancidification. Lancet 2:684-688

17. Torday JS, Hua J, Slavin R 1995 Metabolism and fate of neutral lipids of fetal lung fibroblast origin. Biochim Biophys Acta 1254:198-206

18. Rodriguez A, Viscardi RM, Torday JS 2001 Fetal androgen exposure inhibits petal rat lung fibroblast lipid uptake and release. Exp Lung Res 27:13-24

19. Nunez JS, Torday JS 1995 Fetal rat lung type II cells and fibroblasts actively recruit surfactant substrate. J Nutr 125(supp16):1639S-1644S

20. Smith BT, Giroud CIP 1975 Effects of cortisol on serially propagated fibroblast cell cultures derived from the rabbit fetal lung and skin. Can J Physiol Pharmacol 53:1037-1041

21. Hamosh M, Simon MR, Canter Jr H, Hamosh Pl 1978 Lipoprotein lipase activity and blood triglyceride levels in fetal and newborn rats. Pediatr Res 12:1132-1136

22. Spitz DR, Malcolm RR, Roberts RJ 1990 Cytotoxicity and metabolism of 4-hydroxy-2 nonenal and 2-nonenal in $\mathrm{H}_{2} \mathrm{O}_{2}$-resistant cell lines. Biochem J 267:453-459

23. Gille JJ, Joenje H 1992 Cell culture models for oxidative stress: superoxide and hydrogen peroxide versus normobaric hyperoxia. Mutat Res 275:405-414

24. Torday JS 1992 Cellular timing of fetal lung development. Semin Perinatol 16:130 139

25. Floros J, Nielsen HC, Torday JS 1987 Dihydrotestosterone blocks fetal lung fibroblast pneumocyte factor at a pretranslational level. J Biol Chem 262:13592-13598

26. Fridovich I 1976 Oxygen radicals, hydrogen peroxide, and oxygen toxicity. In: Prior WA (ed) Free Radicals in Biology, Vol 1. Academic Press, New York, pp 239-277

27. Frank L, Groseclose EE 1984 Preparation for birth into an $\mathrm{O}_{2}$-rich environment: the antioxidant enzymes in the developing rabbit lung. Pediatr Res 18:240-244

28. Frank L, Lewis PL, Sosenko IRS 1985 Dexamethasone stimulation of fetal rat lung antioxidant enzyme activity in parallel with surfactant stimulation. Pediatrics 75:569574

29. Crowley P, Chalmers MJNC 1990 The effects of corticosteroid administration before preterm delivery: an overview of the evidence from controlled trials. Br J Obstet Gynaecol 97:11-25

30. Frank L, Bucher JR, Roberts RJ 1978 Oxygen toxicity in neonatal and adult animals of various species. J Appl Physiol 45:699-704

31. Sosenko IRS, Innis SM, Frank L 1988 Polyunsaturated fatty acids and protection of newborn rats from oxygen toxicity. J Pediatr 112:630-637

32. Neriishi K, Frank L 1984 Castration prolongs tolerance of young male rats to pulmonary $\mathrm{O}_{2}$ toxicity. Am J Physiol 247:R475-R481

33. Frank L, Sosenko IRS 1987 Prenatal development of lung antioxidant enzymes in four species. J Pediatr 110:106-110

34. Kaplan NB, Grant MM, Brody JS 1985 The lipid interstitial cell of the pulmonary alveolus. Am Rev Respir Dis 132:1307-1312

35. Sosenko IR, Lewis PL, Frank L 1986 Metyrapone delays surfactant and antioxidant enzyme maturation in developing rat lung. Pediatr Res 20:672-675 